\title{
GMR
}

\section{Structure and genetic diversity of Anacardium humile (Anacardiaceae): a tropical shrub}

\author{
L.G. Cota ${ }^{1}$, P.A. Moreira ${ }^{2}$, M.M. Brandão ${ }^{1}$, V.A. Royo ${ }^{1}$, A.F. Melo Junior ${ }^{1}$, \\ E.V. Menezes ${ }^{1}$ and D.A. Oliveira ${ }^{1}$ \\ ${ }^{1}$ Laboratório de Bioprospecção e Recursos Genéticos, \\ Departamento de Biologia Geral, Universidade Estadual de Montes Claros, \\ Campus Universitário Professor Darcy Ribeiro, Montes Claros, MG, Brasil \\ ${ }^{2}$ Departamento de Biologia, Instituto de Ciências Exatas e Biológicas, \\ Universidade Federal de Ouro Preto, Campus Morro do Cruzeiro, Ouro Preto, \\ MG, Brasil \\ Corresponding author: E.V. Menezes \\ E-mail: menezes.elytania@gmail.com \\ Genet. Mol. Res. 16 (3): gmr16039778 \\ Received July 17, 2017 \\ Accepted August 29, 2017 \\ Published September 27, 2017 \\ DOI http://dx.doi.org/10.4238/gmr16039778
}

Copyright $(2017$ The Authors. This is an open-access article distributed under the terms of the Creative Commons Attribution ShareAlike (CC BY-SA) 4.0 License.

ABSTRACT. Anacardium humile Saint Hilaire is a tropical shrub
native to the Cerrado biome. It is a fruiting species with biological,
medicinal, and socioeconomic significance. Thus, knowing how the
genetic variability of natural populations is organized allows for the
establishment of strategies for conservation and the sustainable use of
the species and its biome. Six microsatellite loci previously developed
from Anacardium occidentale were used to investigate the spatial
genetic structure and genetic diversity of eight natural A. humile
populations based on analyses of 242 adult plants. The results obtained
indicate that these populations show a high level of genetic diversity
(expected heterozygosity $=0.710$ ). The endogamy coefficient was
positive and significant for most populations, with a mean of $0.142(\mathrm{P}$
$=0.001)$. The genetic differentiation between populations was low $(\theta$
$=0.075$ and $\left.G_{\mathrm{ST}}=0.066\right)$ but significant $(\mathrm{P}=0.0001)$. The genotypes

Genetics and Molecular Research 16 (3): gmr16039778 
of five of the eight populations were non-randomly distributed with clusters of related plants for which the coancestry values were positive and significant. These populations exhibited high and significant endogamy indices. The results obtained for $A$. humile populations show that genetic conservation programs should be implemented to maintain this species.

Key words: Cashew of Cerrado; Microsatellite markers; Cerrado; Structure and genetic diversity

\section{INTRODUCTION}

Changes in tropical landscapes resulting from fragmentation accentuate the loss of genetic diversity as they reduce population sizes. When small populations become isolated and thus more susceptible to effects associated with endogamy, genetic drift, and absent and/or limited gene flow (Frankham et al., 2002), and also the capacity of a species to evolve suffers (Hamrick, 2004). Therefore, maintaining genetic diversity is critical, as it is a fundamental component of biological diversity and allows species to adapt to environments through a constant process of transformation (Frankham et al., 2002).

In recent years, tropical biomes have been greatly degraded, making their conservation of utmost importance. This is especially true for the Cerrado, the second largest Brazilian biome, which contains great biological diversity and many habitats and is the source of various natural resources (Cavalcanti and Joly, 2002). The Cerrado is considered a global biodiversity hotspot based on the anthropic impacts it has suffered, the number of endemic species it houses, and the high level of species diversity in general (Myers et al., 2000).

The Cerrado has suffered great damage from alterations to its landscape due to the expansion of human activities in the region, such as the use of the land for agriculture and ranching, exploitation of the native flora and fauna, and predatory extractivism (Henriques, 2003). These activities have put the biodiversity of Cerrado at risk, and early studies on this topic looked at the accelerated fragmentation of its natural habitats (Machado et al., 2004). Thus, the Cerrado is an interesting region for studying the effects of human occupation on the genetics of plant populations and how genetic variation relates to the characteristics of life history (Collevatti et al., 2010).

Numerous studies on the genetic conservation of native Cerrado plant species have been carried out, analyzing these populations using microsatellite molecular markers (Zucchi et al., 2003; Moura et al., 2009; Collevatti et al., 2010; Tarazi et al., 2010). This technique is widely used because it is codominant, highly polymorphic and informative (Tautz, 1989; Guichoux et al., 2011).

Interest in genetic studies of natural populations that combine evolutionary biology and ecology has increased in recent years (Frankham et al., 2002). Quantifying the levels of genetic diversity and understanding how populations are genetically structured allow for the identification of populations and priority sites for conservation. Additionally, it is possible to monitor long-term changes in gene flow, endogamy levels, genetic structure, and effective population sizes of species in altered habitats and/or exploited species (Gibbs, 2001; Frankham et al., 2002). These conservation activities integrate genetics with demographic and environmental variables, catastrophes, and human impact to predict extinction risks, and compare alternative options in species recovery programs (Frankham, 2003).

Genetics and Molecular Research 16 (3): gmr16039778 
This study aims to assess how natural populations of Anacardium humile, an important tropical shrub species native to the Cerrado biome, are genetically structured. The level of genetic diversity was quantified in these populations to obtain information for the conservation, management, and appropriate use of the species and its biome.

\section{MATERIAL AND METHODS}

\section{Species studied}

A. humile Saint Hilaire is a tropical fruiting species in the Anacardiaceae family. The species is commonly known as cashew of Cerrado because it is native to rocky savannas in the Cerrado biome (Almeida et al., 1998). The A. humile is a hermaphroditic shrub measuring up to $80 \mathrm{~cm}$ (Almeida et al., 1998), with white flowers, diurnal anthesis, a nectar scent, and is pollinated by small insects such as bees and butterflies (Martins and Batalha, 2006). However, there are no detailed studies on its reproductive system. The cashew of $A$. humile has similar features and use of the related species cashed nut Anacardium occidentale, the only species of cashew tree cultivated in tropics. As with the A. humile, other species of the genus are native and exploited by extractivism. The pseudo fruit of $A$. humile has an acidic flavor and juicy white pulp and is consumed in natura or in the form of juices, sweets, and jams. Nearly all parts of the plant are used in folk medicine (Almeida et al., 1998; Vieira et al., 2006; Porto et al., 2008).

A. humile is a heliophile with a subterraneous stem that can stretch nearly $20 \mathrm{~m}$. The stem stores water, allows the species to withstand long droughts and protects it from fires. Thus, the species has features that make it resistant to the particular environmental water stresses of the Cerrado (Almeida et al., 1998).

\section{Study areas}

Eight natural A. humile populations were selected from the Cerrado biome in the North of Minas Gerais State (Figure 1). Two populations (BAL and CAT) were in a conservation unit (APA Pandeiros) (IEF - Instituto Estadual de Florestas, 2011). The other six populations were from diversified areas and private properties that predominantly had Cerrado vegetation, with some areas that had pastures and had undergone native flora lumber extraction, while others were in a better state of conservation (Table 1). The physiognomic features of Cerrado biome were classified according to Bitencourt et al. (1997). The method proposed by Santos and Vieira (2005) was used to assess the conservation state of the sampling areas, which involved assessing the presence of livestock, fire, and selective cutting to assign a score from 1 to 5 for each area (Table 1).

\section{Sampling, DNA extraction, and microsatellite analysis}

A total of 242 A. humile adult plants were collected from the eight populations and georeferenced (Table 1). The minimum distance between plants collected within a population set was approximately $50 \mathrm{~m}$, given that the stem is subterraneous and could stretch up to 20 $\mathrm{m}$ in diameter. Young leaves were collected from each plant for DNA extraction following the protocol proposed by Doyle and Doyle (1987).

Genetics and Molecular Research 16 (3): gmr16039778 


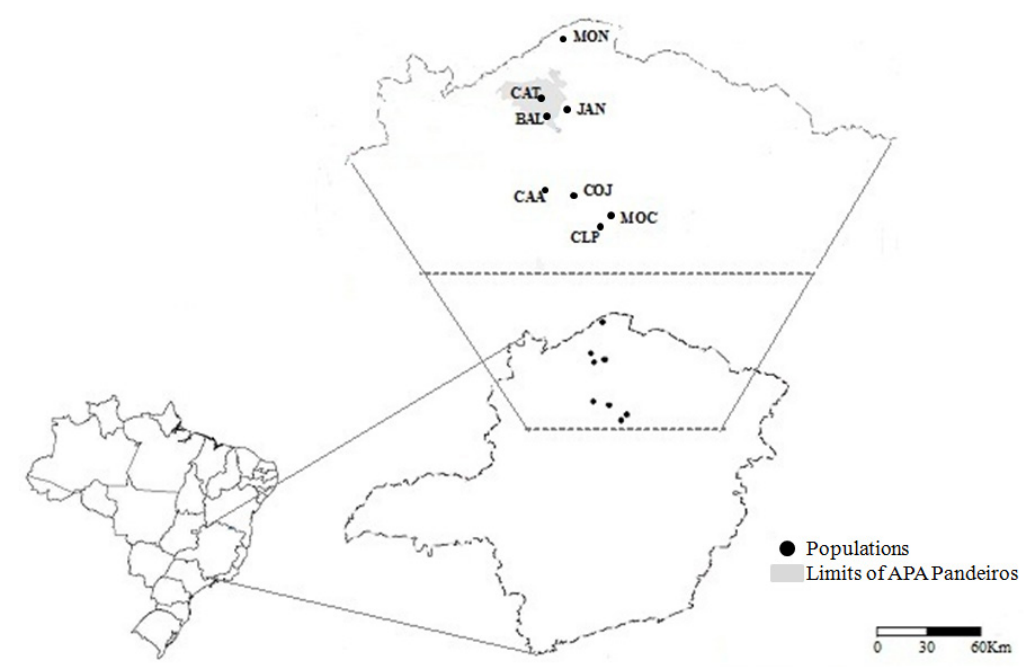

Figure 1. Geographic distribution of the Anacardium humile populations in North of Minas Gerais State. For population names, see Table 1 .

Table 1. Geographical location and sampling details of the Anacardium humile populations studied.

\begin{tabular}{l|c|c|c|l|c}
\hline Populations & Population code & Coordinates & Sample size & Cerrado physiognomies & PS \\
\hline Montalvânia & MON & $14^{\circ} 29^{\prime \prime} 899^{\prime \prime} \mathrm{S} 44^{\circ} 33^{\prime} 106^{\prime \prime} \mathrm{W}$ & 31 & Open cerrado & 3 \\
\hline Coração de Jesus & COJ & $16^{\circ} 34^{\prime} 128^{\prime \prime} \mathrm{S} 44^{\circ} 24^{\prime} 466^{\prime \prime} \mathrm{W}$ & 30 & Cerrado sensu stricto & 5 \\
\hline Montes Claros & MOC & $16^{\circ} 50^{\prime} 615^{\prime \prime} \mathrm{S} 43^{\circ} 55^{\prime} 531^{\prime \prime} \mathrm{W}$ & 30 & Open cerrado & 2 \\
\hline Januária & JAN & $15^{\circ} 26^{\prime} 493^{\prime \prime} \mathrm{S} 44^{\circ} 28^{\prime} 434^{\prime \prime} \mathrm{W}$ & 30 & Closed cerrado & \\
\hline APA Pandeiros & BAL & $15^{\circ} 30^{\prime} 871^{\prime \prime} \mathrm{S} 44^{\circ} 45^{\prime} 176^{\prime \prime} \mathrm{W}$ & 30 & Closed cerrado & 5 \\
\hline APA Pandeiros & CAT & $15^{\circ} 17^{\prime} 336^{\prime \prime} \mathrm{S} 44^{\circ} 49^{\prime} 457^{\prime \prime} \mathrm{W}$ & 31 & Closed cerrado & 5 \\
\hline Claro dos Poções & CLP & $16^{\circ} 59^{\prime} 395^{\prime \prime} \mathrm{S} 44^{\circ} 04^{\prime} 198^{\prime \prime} \mathrm{W}$ & 30 & Open cerrado & 2 \\
\hline Campo Azul & CAA & $16^{\circ} 30^{\prime} 271^{\prime \prime} \mathrm{S} 44^{\circ} 46^{\prime} 113^{\prime \prime} \mathrm{W}$ & 30 & Closed cerrado & 3 \\
\hline Total & & & 242 & & \\
\hline
\end{tabular}

PS $=$ preservation status of the area (method proposed by Santos and Vieira, 2005).

Six microsatellite loci previously developed for $A$. occidentale (Croxford et al., 2006) and transferred to A. humile (Cota et al., 2012) were used in population genetic analyses (Table 2). The $15-\mu \mathrm{L}$ reactions, containing $1 \mathrm{X}$ buffer $(10 \mathrm{mM}$ Tris- $\mathrm{HCl}, \mathrm{pH} 8.4,50 \mathrm{mM} \mathrm{KCl}), 0.7$ $\mu \mathrm{M}$ of each primer, $250 \mu \mathrm{M}$ of each dNTP, $1 \mathrm{U}$ Taq DNA polymerase, $0.25 \mathrm{mg}$ BSA, 1.0 to $1.6 \mathrm{mM} \mathrm{MgCl}, 1.25$ to $3 \%$ formamide, and 9 ng DNA were PCR-amplified using a Veriti thermocycler (Applied Biosystems). The PCR protocol consisted of an initial denaturation at $94^{\circ} \mathrm{C}$ for $5 \mathrm{~min}$, followed by 35 cycles of denaturation at $94^{\circ} \mathrm{C}$ for $1 \mathrm{~min}$, annealing at the primer-specific temperature for $1 \mathrm{~min}$, and extension at $72^{\circ} \mathrm{C}$ for $1 \mathrm{~min}$, and a final extension at $72^{\circ} \mathrm{C}$ for $7 \mathrm{~min}$.

The amplified products were separated on 5\% denaturing polyacrylamide gels stained with $1 \mathrm{mg} / \mathrm{mL}$ ethyl bromide. The size of the alleles was determined by comparison to a standard 50-bp molecular weight marker.

\section{Data analysis}

The genetic diversity was estimated from the number of alleles per locus $\left(N_{\mathrm{A}}\right)$, the

Genetics and Molecular Research 16 (3): gmr16039778 
observed heterozygosity $\left(H_{\mathrm{O}}\right)$, the expected heterozygosity $\left(H_{\mathrm{E}}\right)$ under the Hardy-Weinberg equilibrium, and the endogamy coefficient $(f)$, which were estimated using the Genetic Data Analysis - GDA 1.1 software (Lewis and Zaykin, 2001). The deviation from the HardyWeinberg equilibrium and test for linkage disequilibrium for pairs of loci were assessed using the FSTAT 2.9.3.2 software using permutations with the Bonferroni correction (Goudet, 2002).

Table 2. Characterization of six microsatellite loci in Anacardium humile.

\begin{tabular}{l|l|c|c}
\hline \multirow{2}{*}{ Locus } & Sequence $\left(5^{\prime}-3^{\prime}\right)$ & Repeat motif & AT $\left({ }^{\circ} \mathrm{C}\right)$ \\
\hline \multirow{2}{*}{ mAoR6 } & F: CAAAACTAGCCGGAATCTAGC & $(\mathrm{AT})_{5}(\mathrm{GT})_{12}$ & 58.2 \\
\cline { 2 - 4 } & R: CCCCATCAAACCCTTATGAC & $(\mathrm{GA})_{24}$ & 56.1 \\
\hline \multirow{2}{*}{ mAoR29 } & F: GCAATGTGCAGACATGGTTC & $(\mathrm{TG})_{10}$ & 61 \\
\cline { 2 - 4 } & R: GGTTTCGCATGGAAGAAGAG & $(\mathrm{ACC})_{7}(\mathrm{AC})_{3}$ & \\
\hline \multirow{2}{*}{ mAoR46 } & F: GGAGAAGAAAAGTTAGGTTTGAC & \\
\cline { 2 - 4 } & R: CGTCTTCTTCCACATGCTTC & $(\mathrm{GT})_{16}(\mathrm{TA})_{2}$ & \\
\hline \multirow{2}{*}{ mAoR52 } & F: CGGCGTCGTTAAAGCAGT & 61 \\
\cline { 2 - 4 } & R: TCCTCCTCCGTCTCACTTTC & & \\
\hline \multirow{2}{*}{ mAoR55 } & F: GCTATGACCCTTGGGAACTC & $(\mathrm{AT})_{6} \mathrm{CT}(\mathrm{AC})_{5}$ & \\
\cline { 2 - 4 } & R: GTGACACAACCAAAACCACA & \\
\hline
\end{tabular}

$\mathrm{AT}=$ annealing temperature.

To test whether populations were differentiated, the genetic structure was estimated from the coancestry coefficients of Weir and Cockerham (1984). The coefficients were estimated from the variance of allelic frequencies for the individual plants, with $F$ (total endogamy coefficient), $f$ (endogamy coefficient), and $\theta$ (differentiation between populations), using the FSTAT 2.9.3.2 software, based on 1000 randomizations with the Bonferroni correction (Goudet, 2002).

The genetic differentiation between populations was also estimated using the $G_{\mathrm{ST}}$ index, which is a better measure of genetic differentiation for the mutation rates of microsatellite loci, using the FSTAT 2.9.3.2 software (Goudet, 2002). The significance of the differentiation test was estimated by randomization of the genotypes among the samples to obtain the $\mathrm{G}$ log-likelihood statistic (Goudet, 2002). The genetic differentiation $(\theta)$ between populations was used as the basis for constructing a dendrogram using the UPGMA (unweighted pair-group method with arithmetic averages) method using the NTSYS program, version 2.11X (Rohlf, 2000).

To graphically visualize the differences between the populations, the genetic distance matrix, calculated according to Nei (1978), was used to construct a principal component analysis (PCA) using the GenAlEx 6.1 software (Peakall and Smouse, 2006). The hypothesis of genetic isolation by geographic distance was assessed by the Mantel test using the GenAlEx 6.1 software (Peakall and Smouse, 2006), taking into account the relationship between the Nei genetic distance and the geographic distance $(\mathrm{km})$ among $A$. humile population pairs.

The spatial genetic structure (SGS) of genotypes within populations was analyzed based on the estimated coancestry coefficient. The coancestry value was estimated from the coefficient of kinship between pairs of plants within each population for 10 distinct distance classes, which were not defined a priori, using the SPAGeDI program, version 1.2 (Hardy and Vekemans, 2002).

Confidence intervals were constructed at $95 \%$ probability of the standard error of the mean for the estimates obtained by jackknife resampling, from the estimated mean coancestry coefficient for the distance classes, according to Hardy and Vekemans (2002). One thousand permutations were performed within each class to test for the occurrence of SGS, and its

Genetics and Molecular Research 16 (3): gmr16039778 
magnitude was calculated using the following formula (Vekemans and Hardy, 2004): $S p=-b_{\log }$ $/\left(1-F_{i j(l)}\right)$, where $b_{\log }$ is the slope of the regression curve for the coancestry coefficient and $F_{i j(I)}$ is the value of the coancestry coefficient for the first distance class $\left(F_{i j}\right)$ for all loci. The values for $S p$ were used to compare the extent of spatial genetic structuring between populations.

\section{RESULTS}

\section{Diversity and genetic structure}

The six microsatellite loci evaluated for the A.humile populations produced an average of 5.2 alleles per population (Table 3). The $H_{\mathrm{O}}$ was lower than the $H_{\mathrm{E}}$ for most populations, except for the COJ population. The mean $H_{\mathrm{O}}$ and $H_{\mathrm{E}}$ were 0.611 and 0.710 , respectively (Table 3). The relationship between the $H_{\mathrm{O}}$ and $H_{\mathrm{E}}$ resulted in high and significant endogamy coefficients $(f)$ for the JAN, BAL, CAT, CLP, and CAA populations. Non-significant values for $f$ were found for the MON, MOC, and COJ populations. The COJ population had a negative $f$ value, suggesting the absence of endogamy and a high proportion of heterozygotes, as estimated by $H_{0}$. Nevertheless, the mean of $f$ was positive and significant for the A. humile populations (Table 3). No pair of loci exhibited linkage disequilibrium in the populations analyzed $(\mathrm{P}=0.000042)$ based on 1000 permutations with the Bonferroni correction.

Table 3. Genetic diversity of the eight Anacardium humile populations based on microsatellite loci.

\begin{tabular}{l|c|c|c|c}
\hline Population & $N_{\mathrm{A}}$ & $H_{\mathrm{E}}$ & $H_{\mathrm{O}}$ & $f$ \\
\hline MON & 5.2 & 0.737 & 0.703 & 0.047 \\
\hline COJ & 4.7 & 0.684 & 0.718 & -0.050 \\
\hline MOC & 5.0 & 0.693 & 0.649 & 0.065 \\
\hline JAN & 5.2 & 0.727 & 0.580 & $0.206^{*}$ \\
\hline BAL & 5.7 & 0.725 & 0.604 & $0.170^{*}$ \\
\hline CAT & 5.7 & 0.713 & 0.525 & $0.267^{*}$ \\
\hline CAA & 5.3 & 0.714 & 0.578 & $0.193^{*}$ \\
\hline Over all loci & 5.0 & 0.687 & 0.530 & $0.232^{*}$ \\
\hline
\end{tabular}

$N_{\mathrm{A}}=$ number of alleles; $H_{\mathrm{E}}=$ expected heterozygosity; $H_{\mathrm{O}}=$ observed heterozygosity; $f=$ fixation index. to Table 1.

Values followed by asterisks are significant. For population abbreviations, see legend

The endogamy coefficient $(f)$ and the total endogamy coefficient $(F)$ were significant when compared to mAoR55, mAoR17, and mAoR52 loci, with the latter two loci having higher values. For the mAoR06, mAoR29, and mAoR46 loci, both the $f$ and $F$ values were negative. Nevertheless, the mean estimates for $f(0.139)$ and $F(0.203)$ were significant for the populations $(\mathrm{P}=0.0001)$ (Table 4$)$.

Table 4. Genetic structure of the eight Anacardium humile populations.

\begin{tabular}{l|c|c|c|c}
\hline Locus & $f$ & $F$ & $\theta$ & $G$ \\
\hline mAoR06 & -0.035 & -0.228 & $0.037^{*}$ & $0.033^{*}$ \\
\hline mAoR17 & $0.669^{*}$ & $0.714^{*}$ & $0.136^{*}$ & $0.123^{*}$ \\
\hline mAoR29 & -0.035 & -0.011 & $0.024^{*}$ & $0.021^{*}$ \\
\hline mAoR46 & -0.207 & -0.163 & $0.036^{*}$ & $0.032^{*}$ \\
\hline mAoR52 & $0.636^{*}$ & $0.689^{*}$ & $0.147^{*}$ & $0.131^{*}$ \\
\hline mAoR55 & $0.226^{*}$ & $0.286^{*}$ & $0.078^{*}$ & $0.069^{*}$ \\
\hline
\end{tabular}

$f=$ fixation index; $F=$ total inbreeding coefficient; $\theta$ and $G_{\mathrm{ST}}=$ population differentiation.

Genetics and Molecular Research 16 (3): gmr16039778 
Values followed by asterisks are significant $(\mathrm{P}=0.0001)$.

\section{Genetic differentiation between populations}

The differentiation between the populations was confirmed using the $\theta$ and $G_{\mathrm{ST}}$ indices, which were significant for all loci $(\mathrm{P}=0.0001)$, with means of 0.075 and 0.066 , respectively (Table 4). Values of $\theta$ between the pairs of populations revealed significant genetic differentiation among the eight studied populations (Table 5). The BAL and JAN populations were the least differentiated, while the JAN and MOC populations were the most differentiated.

\section{Table 5. Genetic differentiation (above diagonal) and geographical distances $(\mathrm{km})$ (below diagonal) among the} eight Anacardium humile populations.

\begin{tabular}{l|c|c|c|c|c|c|c|c}
\hline & MON & COJ & MOC & JAN & BAL & CAT & CLP & CAA \\
\hline MON & - & 0.067 & 0.108 & 0.055 & 0.056 & 0.038 & 0.041 & 0.057 \\
\hline COJ & 230 & - & 0.081 & 0.105 & 0.098 & 0.059 & 0.085 & 0.101 \\
\hline MOC & 268 & 60 & - & 0.129 & 0.111 & 0.094 & 0.050 & 0.101 \\
\hline JAN & 105 & 125 & 166 & - & 0.025 & 0.081 & 0.105 & 0.060 \\
\hline BAL & 114 & 122 & 172 & 31 & - & 0.052 & 0.090 & 0.044 \\
\hline CAT & 92 & 148 & 197 & 41 & 26 & - & 0.072 & 0.060 \\
\hline CLP & 280 & 59 & 22 & 177 & 179 & 205 & - & 0.059 \\
\hline CAA & 223 & 39 & 97 & 122 & 110 & 135 & 92 & - \\
\hline
\end{tabular}

For population abbreviations, see legend to Table 1.

The dendrogram constructed using the UPGMAmethod based on genetic differentiation $(\theta)$ revealed the following hierarchical clustering of genetic differentiation, with two groups and approximately 9\% differentiation: [(MON, CAT), ((JAN, BAL), CAA)], [(COJ (MOC, CLP))] (Figure 2).

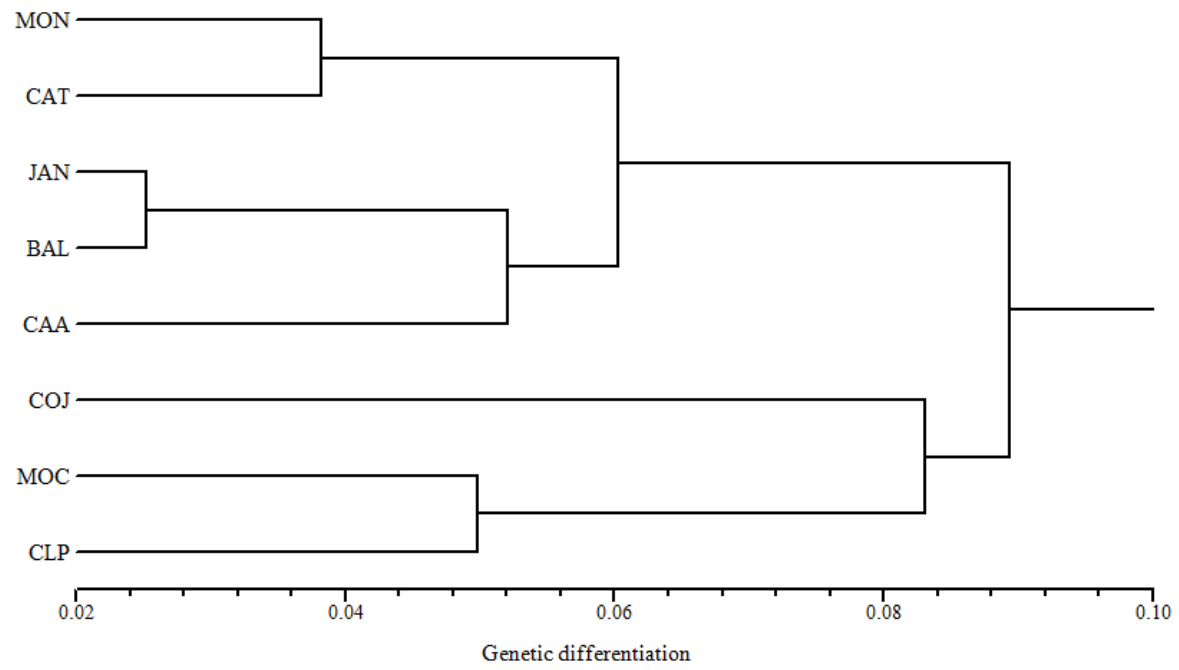

Figure 2. UPGMA dendrogram based on genetic differentiation $(\theta)$ among the eight Anacardium humile populations. For abbreviations, see legend to Table 1.

Genetics and Molecular Research 16 (3): gmr16039778 
The PCA revealed that the first two coordinates explained $59.27 \%$ of the variance in the data; coordinate 1 explained $39.72 \%$ and coordinate 2 explained $19.55 \%$ (Figure 3 ). The results for the estimates of genetic differentiation $(\theta)$ between population pairs (Table 5) corroborated the PCA results. Populations MOC and JAN and MOC and BAL were at opposite ends of coordinate 1 . According to the analysis of genetic differentiation between pairs of populations $(\theta)$, these pairs exhibited the greatest differentiation at 0.129 and 0.111 , respectively.

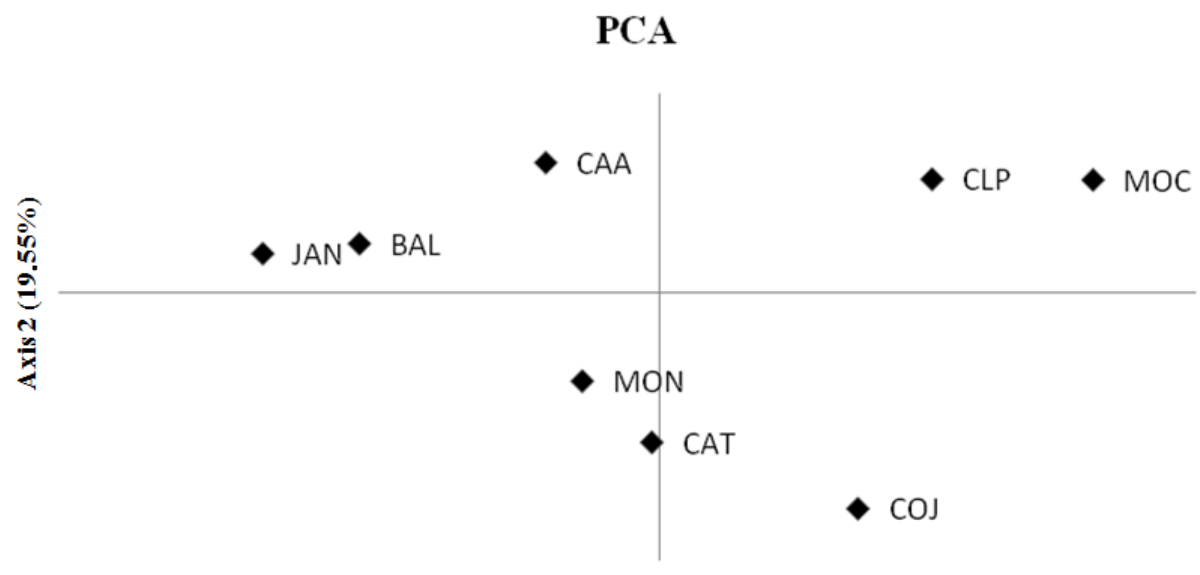

Axis $1(39.72 \%)$

Figure 3. Principal component analysis (PCA) using SSR data among the eight Anacardium humile populations. For population abbreviations, see legend to Table 1.

According to the Mantel test, the correlation between genetic and geographical distances for $A$. humile populations was not explained by the hypothesis of isolation by geographical distance $(r=0.277, \mathrm{P}=0.1)$.

\section{Spatial genetic structure}

Correlogram analysis (Figure 4) revealed a significant SGS for populations MON, JAN, CAT, CLP, and CAA with positive and significant coancestry coefficients $(\mathrm{P}<0.05)$. The SGS of the genotypes in the five populations varied among the distance classes from 37 to $231 \mathrm{~m}$ in the CLP and MON populations, respectively. Populations MON, JAN, CAT, CLP, and CAA exhibited non-random distributions of genotypes in the first distance classes of 231, 118-185, 98-168, 37, and 50-79 m, respectively. These populations, except for MON, had high endogamy coefficients. In populations with SGS, the $f_{i j}$ decreased at a greater distance. Populations COJ, MOC, and BAL exhibited random distributions of genotypes with nonsignificant coancestry coefficients. The values of $S p$ revealed strong genetic structuring for most of the populations: MON $(S p=0.072), \mathrm{COJ}(S p=0.006), \mathrm{MOC}(S p=0.028), \mathrm{JAN}(S p$ $=0.064), \operatorname{BAL}(S p=0.030), \operatorname{CAT}(S p=0.095), \operatorname{CLP}(S p=0.076)$, and CAA $(S p=0.096)$; the mean for the populations was $S p=0.058$.

Genetics and Molecular Research 16 (3): gmr16039778 

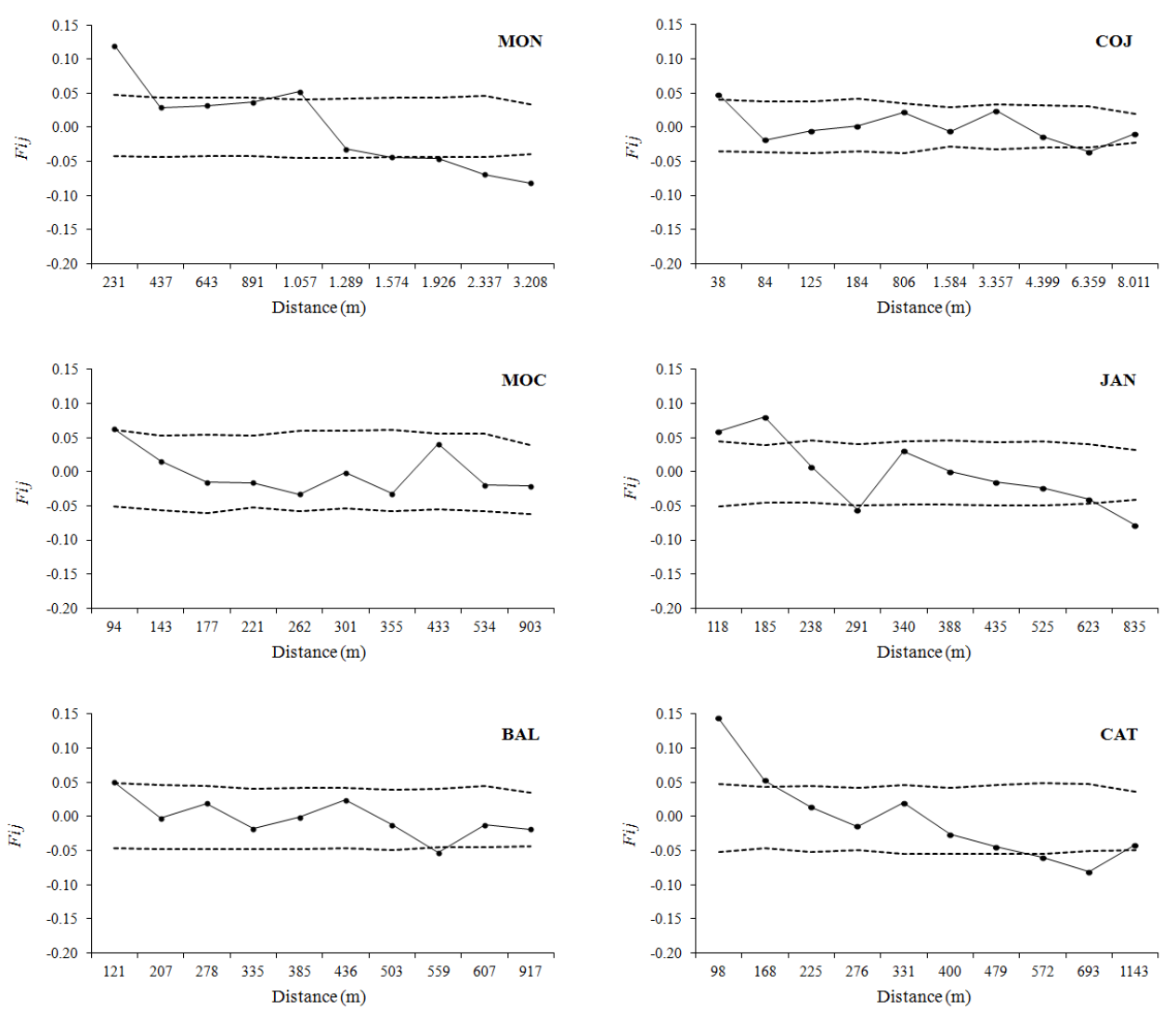

Figure 4. Relationship between kinship $\left(F_{i j}\right)$ and distance among the eight Anacardium humile populations. Confidence intervals (dashed lines) around each $F_{i, j}$ value were obtained through a jackknife procedure over all loci. For population abbreviations, see legend to Table 1.

\section{DISCUSSION}

\section{Diversity and genetic structure}

The $A$. humile populations analyzed exhibited high genetic diversity, despite positive and significant endogamy coefficients for most populations. The levels of diversity in the $A$. humile populations $\left(H_{\mathrm{E}}=0.710, H_{\mathrm{O}}=0.611\right)$ are considered high when compared to other native Cerrado species as Solanum spp (Moura et al., 2009), Caryocar brasiliense (Collevatti et al., 2010), and Dipteryx alata (Tarazi et al., 2010).

Considering that anthropic degradation in the Cerrado biome could have affected the levels of genetic diversity in the populations, no direct relationship was found between more degraded populations and low levels of genetic diversity. However, there was a trend for decreasing diversity due to landscape modifications. Populations MOC, CLP, and CAA are among those with the least alleles and lowest $H_{\mathrm{E}}$ values. These populations are also found in the most degraded areas with the greatest devastation to the native plant cover due to the growing of crops and pastures with an extensive reduction in the native flora. Additionally,

Genetics and Molecular Research 16 (3): gmr16039778 
population CAA suffered heavy extractivism of fruits by the inhabitants of local communities (Leide Cota personal observations - see Table 1). However, the effects of fragmentation were still not observed in the sampled plants, given that they were adults and must have been established before fragmentation.

Some studies have shown that the damaging effects of accelerated degradation in the Cerrado biome on the structure and genetic diversity of species are not visible because the process is recent (Zucchi et al., 2003; Collevatti et al., 2010). However, it is necessary to analyze other generations, such as juveniles and progeny, to assess the effects of fragmentation on $A$. humile. The implications of fragmentation culminate in the loss of genetic diversity in generations established after fragmentation due to, for example, reduction in the effective population size and changes in the behavior of agents that promote gene flow (Ghazoul, 2005). The wild canids that promote the dispersal of $A$. humile should have promoted allelic exchange between the populations analyzed and thus maintained their levels of genetic diversity.

\section{Genetic differentiation between populations}

The genetic relationship between populations, as explained by the axes shown in the PCA graph, does not follow spatial relationship patterns, as geographically close populations are distant from each other on the graph. This finding is confirmed by the Mantel test, which revealed no significant correlation between genetic and geographical distances. Moreover, the estimates of genetic differentiation between populations exhibited the same pattern as the PCA.

The significant genetic differentiation found between $A$. humile, as measured by $\theta$ and $G_{\mathrm{ST}}$, suggest a genetic divergence between the populations although the values obtained were low. This result shows that the previous gene flow between populations over time helped make the allelic frequencies similar among them. This finding is supported by the levels of genetic diversity found in the populations and the low percentage of independent alleles in the populations (data not shown).

Estimates of significant genetic differentiation between natural populations have also been found for other plant species in the Cerrado, such as Eugenia dysenterica (Zucchi et al., 2003), and D. alata (Tarazi et al., 2010). The authors attributed their genetic differentiation to various stochastic processes resulting from isolation by distance, with high gene flow between nearby populations and low gene flow between distant populations. However, such a pattern was not found for the $A$. humile populations. The divergence between the A. humile populations analyzed allows for the establishment of a relationship with the high levels of endogamy found, which contributes to the development of the genetic structure. As suggested by Moreira et al. (2009) for populations of Tabebuia ochracea, a species that is found in the Cerrado, nonrandom crossings can contribute to the formation of genetic structure. Similar conclusions could be inferred from the tropical shrub Erythroxylum havanense (Domínguez et al., 2005), which has significant levels of genetic isolation between neighboring populations and fine SGS. The levels of genetic differentiation between spatially close A. humile populations can also be produced by the presence of the intrapopulational genetic structure.

\section{Spatial genetic structure}

The SGS is correlated with the system of crossing, lifestyle, and population density (Bawa, 1979; Vekemans and Hardy, 2004; Geng et al., 2008; Collevatti et al., 2010). Thus,

Genetics and Molecular Research 16 (3): gmr16039778 
the development of SGS within A. humile populations to form groups of related individuals over short distances could be due to the lifestyle of the species. Individuals of A. humile are distributed in various dense spots that show an aggregated spatial pattern (Inofuentes, 2008), forming clusters of available resources. Thus, it is suggested that the SGS in A. humile populations results from the local restriction of the area foraged by pollinators as a function of the high availability of resources from few individuals. As reported by Bawa (1979), gene flow in plant species is determined by foraging by dispersal agents and pollinators, which depends on their behavior and the availability of resources distributed over time and space. Nevertheless, the same level of SGS can be obtained for a greater density of resources for dispersal agents and pollinators and smaller dispersal distance, or vice versa. Patterns similar to those suggested for the present study, where the non-random distribution of genotypes is a function of the arrangement of individuals in clusters, were suggested for other plant species, such as Kandelia candel (Geng et al., 2008) and C. brasiliense (Collevatti et al., 2010).

The non-random crossings resulting from the presence of factors limiting pollen dispersal could have contributed to the high endogamy coefficients found for most of the populations analyzed in the present study, resulting in the intrapopulational genetic structuring in A. humile populations. Over the long-term, endogamy is a challenge of panmixia and has various effects that can strongly influence the amount of genetic diversity because high homozygosity reduces the effective population size (Charlesworth, 2003). However, this effect has still not culminated in a marked loss of genetic diversity in the populations studied.

In a study on the successional dynamics of A. humile in Cerrado physiognomies, Inofuentes (2008) found that this species was initially established in open physiognomies, continued to develop as the vegetation increased in height and density in closed fields where it reached maximum density, and then decreased in the close Cerrado sensu stricto. A similar pattern was observed in the populations analyzed in the present study (Table 1). Based on these observations, it is possible to highlight the tendency for SGS to occur when there is a greater abundance of the species (populations CAT, MON, CAA, and JAN). When the species is less common, the distribution of genotypes trends toward randomness (populations MOC and COJ). Therefore, it has been shown that factors limiting pollen and seed dispersal to short distances exist at locations with greater population density. Based on the results obtained, it is possible that such factors are strictly related to the distribution of the species resulting in the aggregation of resources for agents that promote gene flow. Therefore, the successional dynamics of the species in Cerrado physiognomies contribute to the development of genetic structure in the populations.

\section{Conclusions and implications for conservation}

The presence of high genetic diversity in the A. humile populations, which reflects the significant genetic variability that still exists in the species, demonstrates the potential for their conservation. Additionally, predatory extractivist exploitation and the anthropic disturbances in the habitats of $A$. humile deserve special attention, as the results show that genetic diversity tends to be lower for populations in more degraded and exploited areas. Appropriated management plans for the extractivist activity must promote the perpetuation of this species and maintenance of its adaptive potential. Therefore, genetic studies on other generations, such as juveniles and progeny, are recommended to assess the effects of fragmentation, permit maintenance of genetic variability, and test for possible genetic differentiation between populations due to frequent and intense modifications to the landscape that reduce the rate at which populations trade alleles.

Genetics and Molecular Research 16 (3): gmr16039778 
The SGS observed in most $A$. humile populations demonstrated that the clusters of related plants produced high coancestry coefficients. Besides, the populations exhibiting SGS also had high levels of endogamy that could promote the development of genetic structure in the populations evaluated. The SGS observed in A. humile populations is possibly related to the habit and lifestyle of the species, which shows successional dynamics in the different Cerrado physiognomies.

\section{Conflicts of interest}

The authors declare no conflict of interest.

\section{ACKNOWLEDGMENTS}

The authors thank CAPES for the Master's scholarship to L.G. Cota and Doctoral scholarship to P.A. Moreira. We also acknowledge research support by FAPEMIG (\#APQ02003-09) through an Incentive to Research and Technological Development Grant (BIPDT) for D.A. Oliveira and a Training Program grant (PCRH) for A.F. Melo Júnior. The State Forestry Institute (IEF) assisted in collecting the samples and data. Finally, we acknowledge Montes Claros State University (UNIMONTES) for logistical support.

\section{REFERENCES}

Almeida SP, Proença CEB, Sano SM and Ribeiro JF (1998). Cerrado: espécies vegetais úteis. Embrapa - CPAC, Planaltina. Bawa KS (1979). Breeding systems of trees in a tropical wet Forest. N. Z. J. Bot. 17: 521-524. https://doi. org/10.1080/0028825X.1979.10432567

Bitencourt MD, Mesquita-Junior HN, Mantovani W, et al. (1997). Identificação de fisionomias de Cerrado com imagem índice de vegetação. In: Anais do $3^{\circ}$ Congresso de Ecologia do Brasil, Brasília.

Cavalcanti RB and Joly CA (2002). Biodiversity and Conservation Priorities in the Cerrado Region. In: The Cerrados of Brazil: ecology and natural history of a Neotropical savanna (Oliveira PS and Marquis RJ, eds.). Columbia University Press, New York, 351-367.

Charlesworth D (2003). Effects of inbreeding on the genetic diversity of populations. Philos. Trans. R. Soc. Lond. B Biol. Sci. 358: 1051-1070. https://doi.org/10.1098/rstb.2003.1296

Collevatti RG, Lima JS, Soares TN and Telles MPC (2010). Spatial Genetic Structure and Life History Traits in Cerrado Tree Species: Inferences for Conservation. Braz. J. Nat. Conserv 8: 54-59. https://doi.org/10.4322/natcon.00801008

Cota LG, Moreira PA, Menezes EV, Gomes AS, et al. (2012). Transferability and characterization of simple sequence repeat markers from Anacardium occidentale to A. humile (Anacardiaceae). Genet. Mol. Res. 11: 4609-4616. https:// doi.org/10.4238/2012.October.17.7

Croxford AE, Robson M and Wilkinson MJ (2006). Characterization and PCR multiplexing of polymorphic microsatellite loci in cashew (Anacardium occidentale L.) and their cross-species utilization. Mol. Ecol. Notes 6: 249-251. https:// doi.org/10.1111/j.1471-8286.2005.01208.x

Domínguez CA, Abarca CA, Eguiarte LE and Molina-Freaner F (2005). Local genetic differentiation among populations of the mass-flowering tropical shrub Erythroxylum havanense (Erythroxylaceae). New Phytol. 166: 663-672. https:// doi.org/10.1111/j.1469-8137.2005.01359.x

Doyle JJ and Doyle JL (1987). Isolation of plant DNA from fresh tissue. Focus 12: 13-15.

Frankham R (2003). Genetics and conservation biology. C. R. Biol. 326 (Suppl 1): S22-S29. https://doi.org/10.1016/ S1631-0691(03)00023-4

Frankham R, Ballou JD and Briscoe DA (2002). Conservation Genetics. Cambridge University Press, Cambridge.

Geng Q, Lian C, Goto S, Tao J, et al. (2008). Mating system, pollen and propagule dispersal, and spatial genetic structure in a high-density population of the mangrove tree Kandelia candel. Mol. Ecol. 17: 4724-4739. https://doi.org/10.1111/ j.1365-294X.2008.03948.x

Ghazoul J (2005). Pollen and seed dispersal among dispersed plants. Biol. Rev. Camb. Philos. Soc. 80: 413-443. https:// doi.org/10.1017/S1464793105006731

Genetics and Molecular Research 16 (3): gmr16039778 
Gibbs JP (2001). Demography versus habitat fragmentation as determinants of genetic variation in wild populations. Biol. Conserv. 100: 15-20. https://doi.org/10.1016/S0006-3207(00)00203-2

Goudet J (2002). FSTAT, a program to estimate and test gene diversities and fixation indices (version 2.9.3.2). Available at [http://www.unil.ch/izea/softwares/fstat.html]. Accessed August 16, 2011.

Guichoux E, Lagache L, Wagner S, Chaumeil P, et al. (2011). Current trends in microsatellite genotyping. Mol. Ecol. Resour: 11: 591-611. https://doi.org/10.1111/j.1755-0998.2011.03014.X

Hamrick JL (2004). Response of forest trees to global environmental changes. For. Ecol. Manage. 197: 323-335. https:// doi.org/10.1016/j.foreco.2004.05.023

Hardy O and Vekemans X (2002). SPAGeDi 1.2: a versatile computer program to analyse spatial genetic structure at the individual or population levels. Mol. Ecol. Notes 2: 618-620. Available at [http://www.ulb.ac.be/sciences/lagev/ software.html]. Accessed August 18, 2011.

Henriques RPB (2003). O futuro ameaçado do Cerrado brasileiro. Cienc. Hoje 33: 34-39.

IEF - Instituto Estadual de Florestas (2011). Áreas Protegidas Estaduais. Available at [http://www.ief.mg.gov.]. Accessed August 10, 2011.

Inofuentes PSP (2008). Anacardium humile St.-Hil. (Cayú of cerrado) in the succession dynamic of Cerrado physiognomies (Chiquitos Province, Santa Cruz). Tesis de Grado, Universidad Mayor de San Andrés, Facultad de Ciencias Puras y Naturales Carrera de Biología.

Lewis PO and Zaykin D (2001). Genetic Data Analysis: computer program for the analysis of allelic data, version 1.0. Available at [http://lewis.eeb.uconn.edu/lewishome/software.html]. Accessed August 16, 2011.

Machado RB, Ramos Neto MB, Pereira PGP, Caldas EF, et al. (2004). Estimativas de perda da área do Cerrado brasileiro. Relatório técnico. Conservação Internacional, Brasília.

Martins FQ and Batalha MA (2006). Pollination systems and floral traits in cerrado woody species of the Upper Taquari region (central Brazil). Braz. J. Biol. 66 (2A): 543-552. https://doi.org/10.1590/S1519-69842006000300021

Moreira PA, Fernandes GW and Collevatti RG (2009). Fragmentation and spatial genetic structure in Tabebuia ochracea (Bignoniaceae) a seasonally dry Neotropical tree. For. Ecol. Manage. 258: 2690-2695. https://doi.org/10.1016/j. foreco.2009.09.037

Moura TM, Sebbenn AM, Chaves LJ, Coelho ASG, et al. (2009). Diversidade e estrutura genética espacial em populações fragmentadas de Solanum spp. do Cerrado, estimadas por meio de locos microssatélites. Sci. For. 37: 143-150.

Myers N, Mittermeier RA, Mittermeier CG, da Fonseca GA, et al. (2000). Biodiversity hotspots for conservation priorities. Nature 403: 853-858. https://doi.org/10.1038/35002501

Nei M (1978). Estimation of average heterozygosity and genetic distance from a small number of individuals. Genetics 89: 583-590.

Peakall R and Smouse PE (2006). GenAlEx 6: genetic analysis in Excel. Population genetic software for teaching and research. Mol. Ecol. Notes 6: 288-295. https://doi.org/10.1111/j.1471-8286.2005.01155.x

Porto KRA, Roel AR, Silva MM, Coelho RM, et al. (2008). Atividade larvicida do óleo de Anacardium humile Saint Hill sobre Aedes aegypti (Linnaeus, 1762) (Diptera, Culicidae). Rev. Soc. Bras. Med. Trop. 41: 586-589. https://doi. org/10.1590/S0037-86822008000600008

Rohlf FJ (2000). Numerical taxonomy and multivariate analysis system. Version 2.11. Applied Biostatistics, New York.

Santos RM and Vieira FA (2005). Análise estrutural do componente arbóreo de três áreas de cerrado em diferentes estádios de conservação no município de Três Marias, Minas Gerais, Brasil. Cerne 11: 399-408.

Tarazi R, Moreno MA, Gandara FB, Ferraz EM, et al. (2010). High levels of genetic differentiation and selfing in the Brazilian cerrado fruit tree Dipteryx alata Vog. (Fabaceae). Genet. Mol. Biol. 33: 78-85. https://doi.org/10.1590/ $\underline{\mathrm{S} 1415-47572010005000007}$

Tautz D (1989). Hypervariability of simple sequences as a general source for polymorphic DNA markers. Nucleic Acids Res. 17: 6463-6471. https://doi.org/10.1093/nar/17.16.6463

Vekemans X and Hardy OJ (2004). New insights from fine-scale spatial genetic structure analyses in plant populations. Mol. Ecol. 13: 921-935. https://doi.org/10.1046/j.1365-294X.2004.02076.x

Vieira RF, Costa TSA, Silva DB, Ferreira FR, et al. (2006). Frutas Nativas da Região Centro-Oste do Brasil. Embrapa Recursos Genéticos e Biotecnologia, Brasília.

Weir BS and Cockerham CC (1984). Estimating F-statistics for the analysis of population structure. Evolution 38: 1358-1370.

Zucchi MI, Brondani RPV, Pinheiro JB, Chaves LJ, et al. (2003). Genetic structure and gene flow in Eugenia dysenterica DC in the Brazilian Cerrado utilizing SSR markers. Genet. Mol. Biol. 26: 449-457. https://doi.org/10.1590/S1415$\underline{47572003000400008}$

Genetics and Molecular Research 16 (3): gmr16039778 